\title{
Escherichia coli 0157:H7 in the context of foodborne diseases and public health
}

\author{
Alejandro de Jesús Cortés-Sánchez ${ }^{1 *}$, María de la Paz Salgado-Cruz ${ }^{2}$ \\ ${ }^{1}$ Consejo Nacional de Ciencia y Tecnología (CONACYT), Centro de Investigaciones Biológicas del Noroeste, S.C. Unidad Nayarit, \\ Calle Dos No. 23. Cd. Del conocimiento, Av. Emilio M. González, Cd. Industrial, C.P. 63173, Tepic, Nayarit, México \\ ${ }^{2}$ Consejo Nacional de Ciencia y Tecnología (CONACYT), Instituto Politécnico Nacional, Escuela Nacional de Ciencias Biológicas, \\ Unidad Profesional Zacatenco, Prolongación de Carpio y Plan de Ayala s/n, Santo Tomás, 11340 Miguel Hidalgo, Ciudad de México, \\ México \\ ${ }^{*}$ Corresponding author, E-mail: alecortes_1@hotmail.com
}

\begin{abstract}
Foodborne diseases are a major issue and challenge in public health due to their morbidity and negative repercussions on health and economy for the population. The foodborne diseases have causal agents, being more frequent those of biological origin as Escherichia coli, which is considered a normal inhabitant of the intestinal microbiota in humans and animals. This microorganism represents different pathogenic groups such as enterohemorrhagic (E. coli O157:H7), which is considered an emerging pathogen with high incidence, mortality and severe sequelae. Its infection is generally through the consumption of contaminated meat products, and mainly affecting children and adults. The objective of this paper is to provide an overview of foodborne diseases and causative agents, such as enterohaemorrhagic E. coli O157:H7, including isolation procedures in the microbiological laboratory, sanitary regulation of major food carriers, treatment of infection and incidence of antimicrobial resistance, prevention and control measures through the main food vehicle propagation, all of which promote protection of the health of the population.
\end{abstract}

Key words: Escherichia coli, food safety, public health.

Abbreviations: $\mathrm{CFU}$, colony-forming units; FD, foodborne diseases.

\section{Foodborne diseases}

Foodborne diseases (FD) are those diseases caused by the consumption of water or foods contaminated with chemical or microbiological agents. Water and food contamination can be generated at any time due to deficiencies or bad practices at different stages of the food chain (processing, handling, conservation, transport, distribution or marketing and service; Zamudio et al. 2011; Lopez et al. 2014; Badui 2015). FD are classified as foodborne infections or poisonings and constitute a major global public health problem and challenge due to their incidence and mortality, and effect on the health and quality of life of the population, mainly the poor, children, pregnant women and elderly, which result in economic losses and high costs to health services, as well as for the execution of inspection procedures and laboratory analysis for detection in food (Rojas-Herrera, González-Flores 2006; Perez et al. 2008; Zamudio et al. 2011; Puig et al. 2013a; Puig et al. 2013b).

More than 250 causative agents of foodborne diseases have been described, including bacteria, fungi, prions, viruses, parasites, toxins and metals. The most frequent causal agents are of bacterial origin, among them genera belonging to enterobacteria such as Salmonella spp.,
Shigella spp., Yersinia spp., and Escherichia coli as well as Gram positive species like Staphylococcus aureus, Bacillus cereus, Listeria monocytogenes, Clostridium Perfringens, Clostridium botulinum, among others (Rojas-Herrera, González-Flores 2006; Boric 2008; Puig et al. 2013a). The occurrence of these diseases has been increasing in recent years due to factors such as the modernisation, commercialisation and globalisation of the food industry, demographic changes and changes in eating habits. The challenge against foodborne diseases increases due to the emergence of new forms of transmission, vulnerable population groups and antimicrobial resistant pathogenic microorganisms (Cruza 2010; Palomino, Gonzalez 2014).

Foods generally involved in outbreaks of FD are meats, dairy products, fish, seafood, eggs and vegetables. One of the common symptoms of these diseases caused by microorganisms is diarrhea (Lopez et al. 2014). According to data from the World Health Organisation (WHO), the estimated annual incidence of diarrhea in the world is 1500 million cases, with an annual mortality of 3 million children under 5 years of age, where $70 \%$ of diarrhea is caused by ingestion of food contaminated with microorganisms and/or toxins (Alerte et al. 2012). The US Centre for Disease Control and Prevention has reported 
an estimated 76 million cases per year with an estimated 5000 deaths, while in developing countries a mortality rate of 2 million children per year caused by diarrheal diseases of microbial origin is estimated due to the consumption of contaminated food and water (Massoc 2008).

In the case of Latin America, the WHO estimate of food-borne infections account to approximately $70 \%$ of cases of acute diarrheal disease (Boric 2008). In Mexico, the Ministry of Health reported for 2001 that gastrointestinal diseases caused by bacteria or parasites were the $14^{\text {th }}$ largest cause of death, with the states of Chiapas, Oaxaca, Guanajuato, Veracruz, Puebla and Federal District having the highest incidence. In 2008, the Mexican Institute of Social Security provided 2000188 consultations for gastrointestinal diseases, where the states with the highest incidence were: Chihuahua, Coahuila, Jalisco, Michoacán, Guerrero, and Oaxaca (Hernandez et al. 2011).

Food is a vital biological need for the human being. The population seeks and has the right to consume foods of sensorial, nutritional quality and also with safety, i.e. the guarantee of not causing damage to health. Foodborne diseases can be caused by lack of safety during and at any stage of the food chain and with negative effects on the economy and health of the population where they are generated. As a result of the joint work of both national and international regulations as well as the food industry, it is necessary to implement practices and systems that ensure the production of safe food throughout the food chain, i.e. from the field or farm to the table (Lopez et al. 2014; Palomino, Gonzalez 2014; Badui 2015).

The objective of this review is to provide an overview of foodborne diseases and causative agents, such as enterohaemorrhagic Escherichia coli O157:H7, considered in recent years around the world an emerging pathogen due to the incidence, severity and sequelae of its disease. It also addresses the issue of isolation procedures in the microbiological laboratory, regulation or sanitary regulation of major food carriers, treatment of infection as well as the incidence of antimicrobial resistance, prevention and control measures through food as the main vehicle of propagation, all of which promote protection of the health of the population.

\section{Enterobacteria and the genus Escherichia spp.}

The Enterobacteriaceae family constitutes an extensive and heterogeneous group of gram negative bacteria whose characteristics are in the form of cane, generally 1 to $3 \mu \mathrm{m}$ in length and $0.5 \mu \mathrm{m}$ in diameter, facultative anaerobes, forming capsules, fimbriae, pillis, fermenting glucose with and without gas production, most mobile, do not form spores, oxidase negative and produce catalase. Its name is attributed to its localisation, in a habitual way, like saprophytes in the digestive tube of the man and animals; in free living, they are located in diverse natural environments like the soil, water and vegetation. Some genera belonging to the family of enterobacteria and which have importance in human health, like Citrobacter spp., Proteus spp., Klebsiella spp., Serratia spp., Enterobacter spp., and Escherichia spp., with the latter being the most prevalent microorganism in this microbial group of the coli species (Romero 2007; Puerta, Mateos 2010).

The genus Escherichia is formed by two species: $E$. coli and E. hermanii. E. coli is a free living organism, it is constantly located in fecal matter of man and animals. Its natural habitat is the gastrointestinal system as part of the native microbiota with saprophyte character, and also is an enteropathogen with varying degrees of virulence causing damage and producing different clinical pictures such as inflammatory processes and infections in wounds, respiratory tract, urinary tract and the gastrointestinal system (Rodriguez 2002; Romero 2007; Puerta, Mateos 2010).

Among the characteristics of this microorganism are: a non-sporulating Gram negative bacillus, with a single DNA chain with a total of 5000 genes, mobile with peritric flagella, mesophilic, aerobic and facultative anaerobic, fimbriae, pilis, capsula, fermentation of glucose and lactose with gas production, decarboxylation of lysine and production of indole from tryptophan. Its optimum growth $\mathrm{pH}$ is from 6 to 8 , temperature from 35 to $40{ }^{\circ} \mathrm{C}$ and water activity of 0.995 . It is part of the enterobacterial family and present somatic $\mathrm{O}$, capsular $\mathrm{K}$ and $\mathrm{H}$ flagellar antigens in different combinations to form different serotypes that are sometimes associated with particular clinical conditions such as E. coli O157:H7 (Rodriguez 2002; Romero 2007; Puerta, Mateos 2010; ELIKA 2013).

E. coli is a diverse bacterial group with pathogenic strains being classified into six groups: enteropathogenic, enteroinvasive, enterohemorrhagic, enterotoxigenic, and enteroadherent/enteroagregative. The first four are those involved in food and waterborne diseases. The classification is based on several factors such as the pathogenic and epidemic potential, association to severe diseases in man and animals, capacity to produce outbreaks, mechanism to generate disease and clinical picture which is frequently related to diarrhea (Rodriguez 2002; Cortes et al. 2002; Machanie 2003; Rivas et al. 2006; Torres-Armendáriz 2016; Feng et al. 2016).

Data reported by epidemiological studies in Latin American countries such as Mexico indicate that the most frequent group of pathogenic $E$. coli is enterotoxigenic (48\%), followed by enteroinvasive (9\%), enteropathogen (4\%) and enterohemorrhagic (1\%), isolated among nonO157:H7 E. coli strains. They also indicate that the presence of $E$. coli is greater during the humid and hot months, affecting mainly children under five years. Epidemiological surveillance by Mexican health authorities reports that enteropathogenic E. coli is endemic in up to $6 \%$ of the population (Hernandez et al. 2011). 


\section{Escherichia coli 0157:H7}

E. coli O157:H7 belongs to the group of enterohemorrhagic E. coli. It is a pathogen with the incidence of bloody diarrhea, which presents as a natural reservoir in the gastrointestinal system of cattle, goats, sheep, pigs, dogs, chickens and gulls. Its mechanism of transmission is through the consumption of food and water contaminated by fecal matter of animal carriers, from person to person and direct contact with carrier animals or their feces (Michanie 2003; Rojas et al. 2006; Rivas et al. 2006; Romero 2007; Pennington 2010; Sanchez et al. 2010; Torres-Armendáriz 2016; WHO 2011; Feng et al. 2016). This bacterium has the ability to tolerate and adapt to acidic conditions $(\mathrm{pH} \leq 4)$, unlike others (Benjamin, Datta 1995; Conner et al.2005; ELIKA 2005) and is frequently related to foodborne outbreaks; with poorly cooked beef, cheeses, yogurt, raw milk, unpasteurized fruit juices, recreational water and human consumption, raw and minimally processed vegetables being among the foods implicated in infectious outbreaks (Michanie 2003; Rojas et al. 2006, Rivas et al. 2006; Romero 2007; Pennington 2010; Sanchez et al. 2010; WHO 2011; Torres-Armendáriz 2016; Feng et al. 2016).

E. coli $\mathrm{O} 157: \mathrm{H} 7$ is classified as an emerging pathogen in public health importance worldwide due to the number and severity of outbreaks as well as negative economic repercussions (tourism, industry, product exports, and disease) for the country where they occur (RiverónCorteguera 2002; WHO 2011; Torres-Armendáriz 2016). It has been generally established that different factors have contributed to the emergence of different infectious diseases caused by various pathogens such as E. coli O157:H7 including ecological or environmental changes caused by agricultural or economic development, demographic changes and human behavior, trade and globalisation, development of technology and industry, microbial adaptation (strains resistant to antibiotics), and controversy over public health measures (reduction of programmes and/or inadequate control measures for vectors or reservoirs (Riverón-Corteguera 2002).

E. coli $\mathrm{O} 157: \mathrm{H} 7$ is not the only serological strain that integrates the enterohemorrhagic group, since other enterohemorrhagic strains of sero-varieties have been reported to be present, such as in O26:H11, O111:H8, O103:H2, O113:H21, O104:H21, O121:H19, O111:NM (non-mobile), O145:NM and O104:H4, which have generated infectious outbreaks around the world; yet $E$. coli O157:H7 is the virulent strain most frequently associated with outbreaks of human infections (Michanie 2003; Rivas et al. 2006; Sánchez et al. 2010; Torres-Armendáriz 2016).

Studies have shown and suggest the clinical importance of non-O157:H7 strains whose origin of isolation is the same as O157:H7 (Michanie 2003; Rivas et al. 2006; TorresArmendáriz 2016). The clinical picture of non-O157 strains is characterised by different symptoms such as abdominal pain, watery diarrhea, hemorrhagic colitis, hemolytic uremic syndrome with the capacity to cause outbreaks or isolated cases with high mortality rates (Rodriguez 2002; Sánchez et al. 2010).

The recognition of infection by E. coli O157:H7 is characterised by incubation period of 2 to 12 days, diarrhea with hemorrhagic colitis, nausea, vomiting, abdominal pain and lack or absence of fever with duration of 4 to 10 days, and also with hemolytic uremic syndrome characterised by acute renal failure, hemolytic anemia and thrombocytopenia that can alter other organs such as intestine, pancreas, heart and central nervous system (Rodriguez 2002; Rivas et al. 2006; Romero 2007; Sánchez et al. 2010; WHO 2011). Children younger than 5 years old, elderly and immunocompromised individuals are the most vulnerable groups to infection where recovery from infection can lead to renal, neurological and other sequelae complications. The dose required to become ill appears to be low in the range of 10 to 100 cells per g (Michanie 2003; Rivas et al. 2006; Sánchez et al. 2010; WHO 2011, Feng et al. 2016).

The pathogenic characteristic of this bacterium is associated with different virulence factors such as two main cytotoxins or verotoxins (Stx1 and Stx2), named for their toxic effect in vitro on African green monkey kidney "Vero" cell lines, they are also identical to the toxin produced by type 1 Shigella dysenteriae, and are also known as Shiga toxins (Rivas et al. 2006; Romero 2007; Pennington 2010; Sánchez et al. 2010). The verotoxins have similar mechanisms of action, and their main target is the $28 \mathrm{~S}$ subunit of ribosomal RNA, inhibiting the synthesis of proteins and generating cell death, are specifically susceptible intestinal epithelial cells and endothelial cells of renal blood vessels (Rojas et al. 2006).

However, these toxins show differences in amino acid sequences, immunological reactivity and toxicity in vivo and in vitro. It has been reported that enterohemorrhagic $E$. coli that produce both toxins or only stx 2 is more likely to cause hemolytic uremic syndrome than those that produce only the stx1; in addition, multiple variants of genotypes (stx) have been reported, stx1 is apparently homogeneous. For the stx 2 type more than thirteen variants are known of which stx $2 c, s t x 2 d$ and stx2e have been reported to be more prevalent with Stx2c being generally associated with diarrhea and HUS in humans (Sánchez et al. 2010).

Other factors of virulence are the adhesion factor (intimin) associated to colonisation processes with the destruction of microvilli of the intestinal mucosa and which is encoded in the eaeA gene located on the island of pathogenicity LEE (locus of enterocyte effacement), cytokines such as tumour necrosis factor alpha and interleukin-6, enterohemolysins encoded in the exhA gene of a $90 \mathrm{~kb}$ plasmid, enzymes such as extracellular serine protease and catalase-peroxidase (Rivas et al. 2006; Romero 2007; Pennington 2010; Sánchez et al. 2010), a type III 
secretion system, chemical signal communication to detect cell density and coordinate the expression of quorum sensing genes, and acilhomoserin lactones that intervene in the cell-cell signals between the bacterium and its host, besides being involved in the formation of biofilms and mobility (Torres-Armendáriz 2016).

\section{Microbiological analysis in the laboratory and regulation in food}

E. coli and some of its pathogenic types causing diarrhea in humans are part of the microbiota of the gastrointestinal system of animals and man, which can contaminate food through fecal matter. For several years its presence in water and food is considered as an indicator of food quality and safety by pointing to fecal contamination and possible presence of enteropathogens for humans and animals (Machanie 2003; Piug et al. 2011; Lopez et al. 2014). Apparently there are means by which enterohemorrhagic E. coli can contaminate water and food, adapting to the new conditions, being generally in low proportions and therefore giving greater importance to the infective dose of this pathogen that is relatively low. Therefore, it is necessary to select and use isolation, identification and detection methodologies in foods, especially in those with complex matrices and abundant accompanying microbiota (Rojas et al. 2006).

The identification and isolation of E. coli in the laboratory is by traditional tests that are based on biochemical and serological (phenotypic) characteristics demonstrating the production of metabolites and the presence of antigens (Table 1). Modern analysis include genomic tests that detect the presence of genes coding for different virulence factors (Rodriguez, 2002; Rivas et al.2006; Romero, 2007).

E. coli $\mathrm{O} 157: \mathrm{H7}$ presents characteristic differences in its phenotype that allow the isolation and identification with the rest of $E$. coli in food, being a facultative bacillus that is Gram negative and mobile with flagellar antigen (H7), has low or no metabolism of sorbitol, with absence of $\beta$-glucuronidase activity (4-methylumbelliferyl- $\beta$ D-glucuronide-MUG-negative). This bacterium forms hyaline, gray or colourless colonies of 2 to $3 \mathrm{~mm}$ in diameter on MacConkey sorbitol agar. Likelihood of isolation on this agar can be increased by adding cefixime and telluride (Rodriguez 2002; ELIKA 2005; Pennington 2010; Puerta, Mateos 2010; Torres-Armendáriz,2016; Feng et al. 2016).

The production of Stx1 and Stx2 toxins can be analyzed by in vitro cytotoxicity assays in cultured cells from green monkey kidney, Chinese hamster ovary cells or cervical carcinoma cells, or by immunochemical analysis. Molecular identification tests consist of detecting genes encoding different virulence factors (eaeA, stx 1 and $s t \times 2$ ) such as polymerase chain reaction, random amplification of polymorphic DNA, and pulsed-field gel electrophoresis, which also allow subtypes to be identified for the
Table 1. Different biochemical tests used in the microbiological laboratory for the identification of Escherichia coli (Rodriguez 2002)

\begin{tabular}{lc}
\hline Biochemical test & Result \\
Oxidase & - \\
Indole production & + \\
Methyl Red & + \\
Voges-Proskauer & - \\
Acid and gas of glucose & + \\
\hline Lysine decarboxylase & + \\
Mobility at $36^{\circ} \mathrm{C}$ & + \\
\hline Lactose fermentation & + \\
D-mannitol fermentation & + \\
D-sorbitol fermentation & + \\
Phenylalanine deaminase & - \\
\hline L-arabinose fermentation & + \\
Maltose fermentation & + \\
D-xylose fermentation & + \\
Trehalose fermentation & + \\
Erythritol fermentation & - \\
D-manose fermentation & + \\
Nitrate to nitrite & + \\
Acetate utilization & + \\
Malonate utilization & - \\
Lipase & - \\
Ortho-nitrophenyl- $\beta$-galactopyranoside & + \\
\hline
\end{tabular}

epidemiological analysis (Rodriguez 2002; Puerta, Mateos 2010; Zamudio et al. 2011; Feng et al. 2016).

Several methodologies have been reported, some of them standardized for the laboratory analysis of food samples for the detection of Enterobacteriaceae and specific for E. coli and pathogenic types such as O157:H7. The methods may differ in terms of enrichment conditions, inhibitory substances, differential and selective culture media in order to inhibit accompanying microbiota and achieve isolation and detection. The different methods for its microbiological analysis in foods include the enumeration method (presumptive and confirmatory) for E. coli and coliforms using serial dilutions (Feng et al. 2002) and the Bacteriological Analytical Manual US Food and Drug Administration method. The method recommended by International Organization for Standardization (16654:2001) specifically for the isolation and detection of enterohemorrhagic E. coli is the "Microbiology of food and animal feeding stuffs: Horizontal method for the detection of Escherichia coli O157" (Fig. 1). Others include the method of Feng et al. (2016) in the Bacteriology Analytical Manual of the Food and Drug Administration USA, as well as the MLG 5.09 method "Detection, isolation and identification of Escherichia coli O157:H7 from meat products and carcass and environmental sponges" of the Department of Agriculture of the USA. These methods are based on analysis consisting of different phases, such 


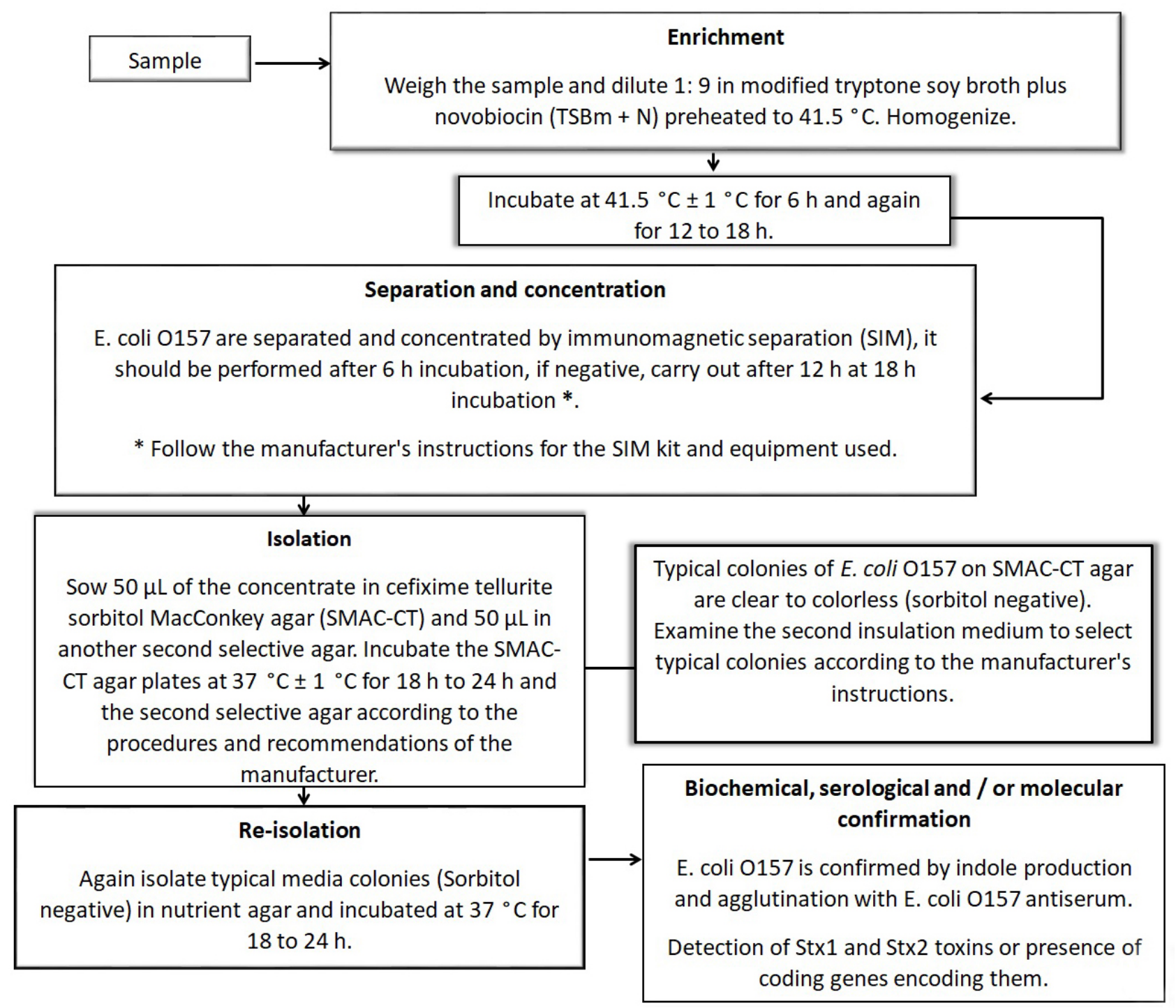

Fig. 1. Flow chart of the method for the isolation and detection of Escherichia coli O157 (ISO 16654:2001).

as enrichment, separation (magnetic immune-separation) and presumptive isolation, biochemical confirmation, and serological and/or molecular (polymerase chain reaction) identification.

Regulations, sanitary criteria and specifications have been established around the world for the surveillance and control of risks to health and food safety, in general referring to $E$. coli in foods with a high potential for contamination risk and transmission of infections to humans, and food industry processes.

In Europe, regarding the regulation of microorganisms in foods like E. coli is through Regulation 2073/2005 of the European Commission of 15 November 2005 concerning the microbiological criteria applicable to foodstuffs established for products such as chopped meat and meat preparations, it specifies E. coli range: 50 to $500 \mathrm{CFU}$ per g during the final phase of the manufacturing process; 50 to $500 \mathrm{CFU}$ per $\mathrm{g}$ in dairy products such as cheese and whey; 100 to $1000 \mathrm{CFU}$ per $\mathrm{g}$ for cut fruit and vegetables ready for consumption and, finally, 100 to $1000 \mathrm{CFU}$ per $\mathrm{g}$ for unpasteurized fruit juices and vegetables during their processing (EC 2005; ELIKA 2013). In some countries of the American continent like Chile, sanitary regulation of food by DTO N 977/96 (DOF 13.05.97) establishes acceptable levels for different foodstuffs for consumption, such as $10 \mathrm{CFU}$ per g cooked meats and ready-to-eat edible fruits and vegetables for $10 \mathrm{CFU}$ per g. On the other hand, in Mexico, the official Mexican standard NOM-194SSA1-2004 establishes microbiological specifications for products regarding the slaughter of animals for supply, storage, transport and sale; with the maximum limit being $1000 \mathrm{CFU}$ per $\mathrm{g}$ for refrigerated products and $5000 \mathrm{CFU}$ per $g$ for refrigerated ground meat. NOM-213-SSA1-2002 establishes sanitary specifications for processed meat 
products, which state that for cooked, cured and marinated products the microbiological indicator for fecal coliforms is $<3 \mathrm{MPN}$ (most probable number) per g product. Finally, the NOM-251-SSA1-2009 standard establishes hygiene practices, which include guidelines for the application of the Hazard Analysis and Critical Control Points system for the food, beverage or nutritional supplements process that must be observed in a mandatory manner in the country in the process of food, beverages or food supplements and their raw materials in order to avoid contamination throughout their process.

\section{Resistance to antimicrobials, E. coli 0157:H7 and food}

Antimicrobial resistance is the ability of a microorganism to tolerate the effects of the chemicals targeted to kill or control their growth. Antimicrobial resistance by microorganisms is considered a worldwide public and animal health problem and challenge due to high rates of morbidity, mortality, treatment difficulty, prolonged disease, increased health costs, and the use of new antimicrobial agents (Garza et al. 2009; Mosquito et al. 2011; Pihr et al. 2011; Verraes et al. 2013; Abd El-Baky 2016).

Antimicrobials are compounds designed and used to fight infections caused by bacteria, improving health, quality and life expectancy in humans and animals. However, improper and indiscriminate use of biocides (chemicals used in the food chain for the cleaning and disinfection of surfaces and equipment) in activities in clinical practice, agriculture and livestock and food processing has promoted the selection of bacteria resistant to different groups of antimicrobials, making them multiresistant and thus conferring them an advantage to widen their ecological niche and facilitate their proliferation in the environment (Holah et al. 2002, Reyes et al. 2004; SilvaSánchez 2006; Garza et al. 2009; Aguayo et al. 2010; Verraes et al. 2013; Cabrera et al. 2007; Lopez et al. 2014; Abd ElBaky 2016).

Microorganisms express their antimicrobial resistance through four different mechanisms: (1) chemical modification of the antimicrobial by adenylation, acetylation, phosphorylation or hydrolysis ( $\beta$-lactamases, which generate the chemical modification of the $\beta$-lactam ring of antibiotics of clinical importance and commonly present in Gram negative bacteria like E. coli, Salmonella sp., Shigella dysenteriae, Pseudomonas aeruginosa, among others); (2) modification of the target site due to mutations in genes encoding the antimicrobial target (RNA polymerase, ribosomal RNA 16S, 23S, PBP and DNA gyrase); (3) change in membrane permeability due to modification of membrane proteins (Porine); and (4) expulsion of the antibiotic by efflux pumps, which prevents access of the antimicrobial to the site of attack in the microorganism. Antimicrobial resistance may be intrinsic (inherent in a genus or species to particular antimicrobials) or acquired (when the strain becomes resistant by a spontaneous mutation due to evolutionary processes or the production of genes coding for resistance). The different mechanisms of resistance are contained in genes located on the bacterial chromosome or mobile genetic elements (plasmids, transposons or integrons), which are transferable horizontally by processes of transformation, transduction or conjugation in different natural environments such as soil, water, gastrointestinal system of human and animal, as well as in foods (Silva-Sánchez 2006; Garza et al. 2009; Lezameta et al. 2010; Verraes et al. 2013; Abd El-Baky 2016). Antimicrobial resistant microorganisms or genetic material that codes for this property can contaminate food through different routes such as: (1) the presence of resistant bacteria in food due to the use of antibiotics during agricultural production i.e. in the early stages of the food chain; (2) the presence of genetic material that encodes resistance, intentionally added during food processing (starter cultures, probiotics, bio conservation and bacteriophages); and (3) cross-contamination with resistant bacteria during processing food. It should be noted that during processing and minimal food preservation, bacterial cells are stressed or subtly damaged, inducing an accumulation of antimicrobial resistance and increasing the risk of transfer of resistance (Verraes et al. 2013).

E. coli has been reported to be highly resistant to various antimicrobials in clinical use, such as ampicillin, trimethoprim-sulfamethoxazole, tetracycline, chloramphenicol, ciprofloxacin and nalidixic acid (Puig et al. 2011; Mosquito et al. 2011; Lopez et al. 2014). For the specific case of E. coli O157:H7, several research groups around the world report the isolation of strains from foods resistant to different antimicrobials. For example, in Nigeria, in a total of 250 samples of beef collected from four different slaughterhouses in the Ibadan metropolitan region, $28 \%$ of isolated E. coli $\mathrm{O} 157: \mathrm{H} 7$ also showed resistance to different antibiotics such as tetracycline, ampicillin, chloramphenicol, cefuroxime, gentamicin, nitrofurantoin and nalidixic acid (Olatoye et al. 2010). In the Middle East in four provinces of Iran, in 3.1\% of a total of 250 samples of traditional dairy products (cheese, ice cream and yogurt); the isolated strains of E. coli O157:H7 showed resistance to ampicillin, gentamicin, erythromycin, amoxicillin, tetracycline and nalidixic acid (Rahimi et al. 2011).

In Mexico, microbiological analysis on 228 paired channel and colon contents of cattle slaughtered from three municipal trails in the central Mexican plateau area obtained a total of eight isolates: six of E. coli O157:H7 (five of channel and one of colon) and two of E. coli O157:NM (of colon) being the first serotype resistant to cefalotin, carbencylin, amikacin and gentamycin (Reyes et al. 2013). In Brazil, in the city of Rio de Janeiro, Kasnowski et al. (2008) collected 30 meat samples from butchers and 
supermarkets under the same conditions that are offered to the consumer, for the isolation and subsequent analysis of antibiotic susceptibility of E. coli strains. This study showed isolations of enteropathogenic, enteroinvasive and enterohemorrhagic E. coli with resistance to antibiotics, mainly ampicillin, cephalothin, amikacin, ceftadizime, gentamicin, cefoxitin, chloramphenicol and tetracycline.

The results of previous investigations reflect theincidence and health risk of pathogen infections through food, so it is necessary to implement actions and hygiene measures at all stages of the food chain to ensure the safety as well as the establishment and/or strengthening of monitoring of antimicrobial use in primary food production (livestock and agriculture) (Kasnowski et al. 2008; Rahimi et al. 2011; Olatoye 2010; Reyes et al. 2013). Research and surveillance of antimicrobial resistance by pathogenic microorganisms allows us to know the profile and mechanisms of resistance that are useful at the epidemiological level, to optimise the surveillance of this phenomenon, antimicrobial control and use policies (Mattar et al. 2001; Mosquito et al. 2011).

\section{Antimicrobial susceptibility and the dichotomy of its use in E. coli 0157:H7 infections}

There is the problem of the increase in the incidence of different pathogenic strains resistant or multiresistant to antimicrobials, which causes difficulty in the treatment and recovery from infections. On the other hand, for enterobacteria and specifically for pathogenic E. coli, the treatment of intestinal infection with antibiotics is controversial, since antibiotic treatment is not recommended because of the reports that excessive use of antibiotics is related to the increase of the resistance phenomenon and, in the specific case of E. coli O157:H7, it is associated with complications of the disease and the increase in the incidence and development of hemolytic uremic syndrome. Therefore, treatment of the infection only supports therapies and management of complications, although cases have been reported where certain antimicrobials administered early in the course of the infection could prevent their progression to the syndrome (Mattar et al. 2001; Reyes et al. 2004; Puerta, Mateos 2010; Sanchez et al. 2010; Mosquito et al. 2011).

The mechanisms by which antimicrobials could increase the risk of developing hemolytic uremic syndrome are not well known, but it is estimated by researchers that it could be associated with bacterial lysis favouring the release of toxins, as well as the elimination of other bacteria present in the intestinal tract, which increases the absorption of toxins at the systemic level, or the induction of bacteriophages (containing genes encoding for toxins) (Sánchez et al. 2010). Studies of alternative treatment modalities against infection by enterohemorrhagic E. coli including soluble toxin receptors and human antitoxin monoclonal antibodies have been reported (Puerta, Mateos 2010; Mosquito et al.
2011), as well as emphasis on measures of prevention and control of the contamination and transmission by the food of this pathogen in all processes involved in the food chain (Acuña, Duncan 2002; Rivas et al. 2006; Pennington 2010; WHO 2011; Badui 2015; Torres-Armendáriz et al. 2016).

\section{Prevention and control of foodborne diseases}

Actions for the prevention and control of contamination and infection by any other pathogens that give rise to foodborne diseases are through the adoption and exercise of practices focused on food production in a way that guarantees the absence of agents harmful to the health of the consumer, such as good agricultural and livestock practices, good manufacturing practices, handling and hygiene, as well as the implementation of Hazard Analysis and Critical Control Point programmes to ensure food safety at all stages of the food chain, from raw materials (agricultural production), manufacturing, transportation, storage, marketing to the preparation of food in the home (Acuña, Duncan 2002; Rivas et al. 2006; Pennington 2010; WHO 2011; Verraes et al. 2013; Badui 2015; TorresArmendáriz et al. 2016). When cattle are considered a natural reservoir and commonly associated with infections and outbreaks of E. coli O157:H7 diseases due to meat consumption, emphasis is placed on the implementation and improvement of systems and hygienic conditions in the management of animals in slaughtering (bleeding, flaying, washing, evisceration and cutting), transportation, storage and preparation of meat products, since the contamination of the carcass meat is due to the transfer of pathogens from the skin, nails and intestines (ELIKA 2005; Olatoye 2010; Reyes et al. 2013;Lopez et al. 2014). Meat constitutes a medium that favors the establishment, survival and multiplication of multiple pathogenic microorganisms, not only of E. coli O157:H7, due to its high moisture content, good qualitative and quantitative composition of nutrients and $\mathrm{pH}$ close to neutral (Reyes et al. 2013; Lopez et al. 2014). It is also necessary to generate educational campaigns and dissemination to the general population about procedures and hygienic conditions suitable for the choice, manipulation, conservation and cooking of water and food where it is known that an effective method for the elimination of E. coli is the application of heat treatment (cooking or pasteurization), as well as maintaining low temperature conditions in the transport, storage and distribution of raw foods that can be contaminated (Mattar et al. 2001; Acuña, Duncan 2002; Rubeglio, Tesone 2007; WHO 2011; ELIKA 2013; Verraes et al. 2013; Lopez et al. 2014; Torres-Armendáriz et al. 2016). In recent years, related alternatives have been developed in food preservation and consumer health protection, since one of the objectives of the food industry is to generate food products with the guarantee and security of not causing consumer illnesses (Garcia et al. 2010; Badui 2015). Within the stages of 
food production are the conservation processes that can be defined as the treatment set that prolongs the useful life, maintaining to a greater degree possible attributes of sensorial and nutritional quality (Sauceda 2011).

Traditional food preservation methods such as freezing, pasteurization, sterilization, dehydration are based on thermal treatments, although effective to guarantee their safety, they have some negative effects on the product, such as the loss or reduction of certain nutrients or alteration of their sensorial characteristics (Garcia et al. 2010; Sauceda 2011). For several years now, alternative technologies have been proposed to traditional methods of preservation, which are used alone or in combination to contribute to the preservation and safety of food, such as pulsed electric fields, high pressure, ionising radiation and ultra-sonication, fluids and other factors, such as the presence of a number of different types of disease (Ross et al. 2003; Tahiri et al. 2006; Toepfl et al. 2007; Oulé et al. 2013). Also, its use in a solitary manner or in combination with other preservation technologies in the food industry is the potential use of phytochemicals, such as essential oils, which have shown antimicrobial effects towards different microorganisms including pathogens; these compounds offer not only a new repertoire of antimicrobials but also contribute to the fight against the phenomenon of resistance to antimicrobials (Cava et al. 2010; Fullerton et al. 2011; Samy et al. 2011; Solorzano-Santos, Miranda-Novales 2012). There has also been interest in the concept of bioconservation, considered a conservation treatment where no heat is applied but is based on the use of the natural microbiota of food and/ or its metabolites of low molecular weight (organic acids) and bacteriocins (compounds of protein origin) that are inhibitors of different pathogenic microorganisms including E. coli and its pathogenic types, as well as the use of altering microorganisms, which prolong the shelf life and increase food safety. Within the application of food bio-conservation the group of lactic acid bacteria are used as starter and probiotic cultures in the preparation and preservation of fermented foods such as milk, meat and vegetables and are an important part of the study of the nutritional and sensorial characteristics of the foods and health of the consumer (Calderon et al. 2007; Roche et al. 2008; Garcia et al. 2010; Roldan et al. 2011; Ramirez et al. 2011; Dosta et al. 2009).

\section{Final comment}

Enterohemorrhagic E. coli is considered in public health an important emerging pathogen transmissible mainly through the food and especially for the consumption of the meat products. Its importance in health lies in its high incidence, mortality and sequelae of the disease, as well as, and although there is discrepancy in the use or antimicrobial use in the therapy, against infections generated by this enterobacteria; the isolation and circulation of resistant strains to antimicrobials contributing to the negative health implications of FD have been reported. For the above, actions and recommendations around the world for the control and prevention of infections by this pathogen have been developed and established. However, it should be emphasized that efforts should be made to collaborate and work together in different sectors, such as the food industry, academia and government sector, in order to design, implement, promote and disseminate actions focused on the prevention and control of this pathogen, which now has characteristics of antimicrobial resistance in the general population through its different routes of transmission, mainly food, improve methodologies of isolation and detection, as well as promote and monitor the rational use of antimicrobials in the production of food and in the clinical area.

\section{Acknowledgements}

The authors have declared that no competing interests exist about this document.

\section{References}

abd El-Baky R.M. 2016. The future challenges facing antimicrobial therapy: resistance and persistence. Am. J. Microbiol. Res. 4: $1-15$.

Acuña W.L., Duncan J.M.G. 2002. Infección por Escherichia coli enterohemorrágica. Revista de la Facultad de Medicina Humana, Universidad Ricardo Palma 3: 38-41.

Aguayo M.C.L., Burgos M.J.G., López R.L., Gálvez A. 2010. Resistencia a biocidas de diferentes cepas de Escherichia coli. Anales de la Real Academia de Ciencias Veterinarias de Andalucía Oriental 23: 121-136.

Alerte V., Cortés A.S., Díaz T.J., Vollaire Z.J., Espinoza M.M.E, Solari G.V., Cerda L.J., Torres H.M. 2012. Foodborne disease outbreaks around the urban Chilean areas from 2005 to 2010. Rev. Chil. Inf. 29: 26-31.

Badui DS. 2015. Inocuidad en la industria alimentaria. Industria Alimentaria, pp. 14-26.

Benjamin M.M., Datta A.R. 1995. Acid tolerance of enterohemorrhagic Escherichia coli. Appl. Environ. Microbiol. 61: 1669-1672.

Boric B.V. 2008. Molecular epidemiology applications to detect illnesses transmitted by food. Latinamerican advances. Biofarbo 16: 92-97.

Cabrera C.E., Gómez R.F., Zúñiga A.E. 2007. La resistencia de bacterias a antibióticos, antisépticos y desinfectantes una manifestación de los mecanismos de supervivencia y adaptación. Colomb. Med. 38: 149-158.

Calderón O., Padilla C., Chaves C., Villalobos L., Arias M.L. 2007. Evaluación del efecto del cultivo probiótico Lactobacillus rhamnosus adicionado a yogurt natural y con probióticos comerciales sobre poblaciones de Staphylococcus aureus, Escherichia coli O157:H7, Listeria monocytogenes y Salmonella enteritidis. Arch. Latinoam. Nutr. 57: 51-55.

Cava-Roda R.M., Taboada-Rodríguez A., Valverde-Franco M.T. Marín-Iniesta F. 2010. Antimicrobial activity of vanillin and mixtures with cinnamon and clove essential oils in controlling Listeria monocytogenes and Escherichia coli O157:H7 in milk. 
Food Bioprocess Technol. 5: 2120-2131

Conner D.E., Kotrola J.S. 1995. Growth and survival of Escherichia coli O157: H7 under acidic conditions. Appl. Environ. Microbiol. 61: 382-385.

Cortés-Ortiz I.A., Rodríguez-Ángeles G., Moreno-Escobar E.A., Tenorio-Lara J.M., Torres-Mazadiego B.P., Montiel-Vázquez E. 2002. Outbreak caused by Escherichia coli in Chalco, México. Salud Pública Mex. 44: 297-302.

DOF. 1997. D.O.F. 13.05.97. República de Chile. Ministerio de salud. División jurídica. Reglamento sanitario de los alimentos. DTO. N 977/96. http://web.minsal.cl/sites/default/ files/2013RSADECRETO_977_96_actualizado2013.pdf. /Accessed May 4, 2017/

Dosta M.C.M., Barrera T.C., Perrino F.J.F., Reyes L.M. 2009. Revisión bibliográfica: Bacteriocinas producidas por bacterias probioticas. ContactoS 73: 63-72.

ELIKA. 2005. Escherichia coli verotoxigénica. http://www. elika.net/datos/riesgos/Archivo2/Escherichia $\% 20$ coli $\% 20$ verotoxig\%C3\%A9nica\%202005.pdf./Accessed May 15, 2017/

ELIKA. 2013. Fundación Vasca para la seguridad agroalimentaria. 28 de febrero, 2013. www.elika.net.http://www.elika.eus/ datos/pdfs_agrupados/Documento84/3.Ecoli.pdf. /Accessed May 25, 2017/

Feng P., Weagant S.D., Grant M.A., Burkhardt W. 2002. Enumeration of Escherichia coli and the coliform bacteria. Bacteriological Analytical Manual. Chapter 4. U.S. Department of Health and Human Services. U.S.Food and Drug Administration. https://www.fda.gov/Food/ FoodScienceResearch/LaboratoryMethods/ucm064948.htm. /Accessed April 5, 2017/

Feng P., Weagant S.D., Jinneman K. 2016. Diarrheagenic Escherichia coli. Bacteriological Analytical Manual. Chapter 4A. February 2011, updated June 2016. U.S. Department of Health and Human Services. U.S. Food and Drug Administration. https://www.fda.gov/Food/FoodScienceResearch/ LaboratoryMethods/ucm070080.htm. /Accessed April 5, 2017/

Fullerton M., Khatiwada J., Johnson J.U., Davis S., Williams L.L. 2011. Determination of antimicrobial activity of sorrel (Hibiscus sabdariffa) on Esherichia coli O157:H7 isolated from food, veterinary, and clinical samples. J. Med. Food 14: 950-956.

García P., Martínez B., Rodríguez L., Rodríguez A. 2010. Endolisinas fagicas: nuevos bioconservantes para alimentos. CTC Alimentación 43: 9-14.

Garza-Ramos U., Silva-Sánchez J., Martínez-Romero E. 2009. Genetics and genomics for the study of bacterial resistance. Salud Pública de Méx. 51: 439-446.

Hernández C., Aguilera M.G., Castro G. 2011. Gastrointestinal diseases, situation in Mexico. Enf. Inf. Microbiol. 31: 137-151.

Hernández Cruza P.E.H. 2010. Bacterias patógenas emergentes transmisibles por los alimentos. Monografías de la Real Academia Nacional de Farmacia. https://www.analesranf. com/index.php/mono/article/view/1111/1128. /Accessed May 20, 2017/

Holah J.T., Taylor J.H., Dawson D.J., Hall K.E. 2002. Biocide use in the food industry and the disinfectant resistance of persistent strains of Listeria monocytogenes and Escherichia coli. J. Appl. Microbiol. 92: 111S-120S.

ISO. 2001. Microbiology of food and animal feeding stuffs Horizontal method for the detection of Escherichia coli O157. International Standard Organization ISO 16654.
Kasnowski C.M., Franco M., Trindade Oliveira L.A., Valente A., Carvalho J.C., Conte-Junior C. 2008. Detección, caracterización serológica y antibiogramas de Escherichia coli aisladas de carne de ternera (babilla) entera y picada. Revista Salud Publica y Nutrición 9: 1-10

Lezameta L., Gonzáles-Escalante E., Tamariz J.H. 2010. Comparación de cuatro métodos fenotípicos para la detección de beta-lactamasas de espectro extendido. Rev. Peru. Med. Exp. Salud Publica 27: 345-351.

López A., Ruiz A.C., Cabrera C., León G., Tejeda F. 2014. Prevalencia de cepas multirresistentes de Salmonella spp y Escherichia coli 0157:H7 en alimentos crudos en la Ciudad de Puebla. In: Ciencias Naturales y Exactas Handbook T-II: Congreso Interdisciplinario de Cuerpos Académicos, ECORFAN, pp. 209-222.

Massoc P.A. 2008. Enfermedades asociadas a los alimentos. Rev. Chil. Infect. 25: 395-397.

Mattar S., Visbal, J., Arrieta G. 2001. E. coli 0157:H7 enterohemorrágico: un agente etiológico de diarrea en Colombia subestimado. Parte II. Revista MVZ Córdoba 6: 81-86.

Michanie S. 2003. Escherichia coli O157:H7 la bacteria que disparó el HACCP en la industria de la carne. Ganados \& Carnes 3: 40-42.

Mosquito S., Ruiz J., Bauer J.L., Ochoa T.J. 2011. Mecanismos moleculares de resistencia antibiótica en Escherichia coli asociadas a diarrea. Rev. Peru Med. Exp. Salud Pública 28: 648-656.

NOM. 2002. NOM-213-SSA1-2002. Norma Oficial Mexicana. Productos y servicios. Productos cárnicos procesados. Especificaciones sanitarias. Métodos de prueba. http://www. economia-noms.gob.mx/noms/inicio.do. /Accessed March 1, 2017/

NOM. 2004. NOM-194-SSA1-2004. Norma Oficial Mexicana. Productos y servicios. Especificaciones sanitarias en los establecimientos dedicados al sacrificio y faenado de animales para abasto, almacenamiento, transporte y expendio. Especificaciones sanitarias de productos. http://www. economia-noms.gob.mx/noms/inicio.do. /Accessed May 1, 2017/

NOM. 2009. NOM-251-SSA1-2009. NORMA Oficial Mexicana, Prácticas de higiene para el proceso de alimentos, bebidas o suplementos alimenticios. http://www.economia-noms.gob. mx/noms/inicio.do / Access March 10, 2017/

Olatoye I.O. 2010. The incidence and antibiotics susceptibility of Escherichia coli O157:H7 from beef in Ibadan Municipal, Nigeria. Afr. J. Biotechnol. 9: 1196-1199.

Oulé K.M., Dickman M., Arul J. 2013. Properties of orange juice with supercritical carbon dioxide treatment. Int. J. Food. Prop. 16: 1693-1710.

Palomino C.C., González M.Y. 2014. Molecular techniques for detection and identification of pathogens in food: advantages and limitations. Rev. Peru. Med. Exp. Salud Pública 31: 535546.

Pennington H. 2010. Escherichia coli O157. Lancet 376: 1428-1435.

Pérez-Cordón G., Rosales M.J., Valdez R.A., Vargas-Vásquez F., Cordova O. 2008. Detección de parásitos intestinales en agua y alimentos de Trujillo, Perú. Rev. Peru. Med. Exp. Salud Pública 25: 144-148.

Puerta G.A., Mateos R.F. 2010. Enterobacterias. Medicine 10: 3426-3431.

Puig P.Y., Brady A.R.M., Leyva C.V.2013b. Epidemiological factors 
of interest in outbreaks of food-borne diseases in Havana. Rev. Cubana Hig. Epidemiol. 51: 262-268.

Puig P.Y., Espino H.M.,Leyva C.V.2011. Resistencia antimicrobiana en Salmonella y E. coli aisladas de alimentos: revisión de la literatura. Panorama Cuba y Salud 6: 30-38.

Puig P.Y., Leyva C.V., Maceo R.B., Muñoz A.P.Y. 2013a. Bacterial agents associated with outbreaks of food-borne diseases in Havana, 2006-2010. Rev. Cubana Hig. Epidemiol. 51: 74-83.

Rahimi E., Chaleshtori S.S., Parsaei P. 2011. Prevalence and antimicrobial resistance of Escherichia coli $\mathrm{O} 157$ isolated from traditional cheese, ice cream and yoghurt in Iran. Afr. J. Microbiol. Res. 5: 3706-3710.

Reglamento (CE) no 2073/2005 de la comisión de 15 de noviembre de 2005. Relativo a los criterios microbiológicos aplicables a los productos alimenticios. (Texto pertinente a efectos del EEE) (DOL 338 de 22.12.2005, p. 1). http://eurlex.europa.eu/ LexUriServ/LexUriServ.do?uri=CONSLEG:2005R2073:2010 0519:ES:PDF. /Accessed March 15, 2017/

Reyes M., Durán C., Prado V. 2004. Antimicrobial susceptibility of Shiga toxin producing E. coli (STEC) strains isolated from human infections and food. Rev. Med. Chile 132: 1211-1216.

Reyes-Rodríguez N.E., Talavera-Rojas M., Varela-Guerrero J.A., Barba-León J., Gutiérrez-Castillo A. D.C., Alonso-Fresán U. 2013. Prevalence and antibiotic resistance of Escherichia coli O157:H7 isolated from bovine carcasses at slaughterhouses of the Central Mexican Plateau. Rev. Mex. Cienc. Pecuarias 4: 235-242.

Rivas M., Miliwebsky E., Chinen I., Deza N., Leotta G.A. 2006. Epidemiologia del síndrome urémico hemolítico en Argentina. Diagnóstico del agente etiológico, reservorios y vías de transmisión. Medicina 66: 27-32.

Riverón-Corteguera R.L. 2002. Enfermedades emergentes y reemergentes: un reto al siglo XXI. Rev. Cubana Pediatr. 74. $7-22$.

Rodríguez A.G. 2002. Diagnosis and main characteristics of Escherichia coli pathogenic groups. Salud Publica Mex. 44: 464-475.

Rojas T., Vásquez Y., Reyes D., Martínez C., Medina L. 2006. Evaluación de la técnica de inmunoseparación magnética para recuperación de Escherichia coli O157: H7 en cremas de leche. Arch. Latinoam. Nutr. 56: 257-264.

Rojas-Herrera R.A., González-Flores T. 2006. Detección e identificación de bacterias causantes de enfermedades transmitidas por alimentos mediante la reacción en cadena de la polimerasa. Bioquimia 31: 69-76.

Roldán M.L., Otero J.L., Villarreal F., Baroni M.R., Carrasco M.S., Álvarez C., Russell-White K., Méndeza E.Á., Simonetta A.C. 2011. Efecto inhibidor de Lactobacillus casei 206/1 contra Escherichia coli O157:H7. Rev. Soc. Ven. Microbiol. 31: 37-41.

Romero Cabello R. 2007. Microbiología y Parasitología Humana: Bases Etiológicas de Enfermedades Infecciosas y Parasitarias. 3ra edición. Editorial medica panamericana.

Ross A.I., Griffiths M.W., Mittal G.S., Deeth H.C. 2003.
Combining nonthermal technologies to control foodborne microorganisms. Int. J. Food Microbiol. 89:125-138.

Rubeglio E.A., Tesone S. 2007. Escherichia coli O157 H7: presencia en alimentos no cárnicos. Arch. Argent Pediatr. 105: 193-194.

Samy S. 2011. Antimicrobial activity of essential oils against vancomycin-resistant enterococci (vre) and Escherichia coli O157:H7 in feta soft cheese and minced beef meat. Braz. J. Microbiol. 42: 187-196

Sánchez S., Martınez R., Alonso J.M., Rey J. 2010. Clinical and pathogenic aspects of infections due to Escherichia coli O157:H7 and other verocytotoxigenic E. coli. Enferm. Infecc. Microbiol. Clin. 28: 370-374.

Sauceda E.N.R. 2011. Uso de agentes antimicrobianos naturales en la conservación de frutas y hortalizas. Ra Ximhai 7: 153-170.

Silva-Sánchez J. 2006. Resistencia a antibióticos. Rev. Latinoam. Microbiol. 48:105-112.

Solorzano-Santos F., Miranda-Novales MG. 2012. Essential oils from aromatic herbs as antimicrobial agents. Curr. Opin. Biotechnol. 23: 136-141.

Tahiri I., Makhlouf J., Paquin P., Fliss I. 2006. Inactivation of food spoilage bacteria and Escherichia coli O157: H7 in phosphate buffer and orange juice using dynamic high pressure. Food Res. Int. 39: 98-105.

Toepfl S., Heinz V., Knorr D. 2007. High intensity pulsed electric fields applied for food preservation. Chem. Eng. Process. Proc. Intens. 46: 537-546.

Torres-Armendáriz V., Manjarrez-Domínguez C.B., AcostaMuñiz C.H., Guerrero-Prieto V.M., Parra-Quezada R.A., Noriega-Orozco L.O., Ávila-Quezada G.D. 2016. Interactions between Escherichia coli O157:H7 and food plants. Has this bacterium developed internalization mechanisms? Rev. Mex. Fitopatol. 34: 64-83.

USDA. 2015. Detection, isolation and identification of Escherichia coli O157:H7 from meat products and carcass and environmental sponges. United States Department of Agriculture,Food Safety and Inspection Service, Office of Public Health Science. Laboratory Guidebook. MLG 5.09. https:// www.fsis.usda.gov/wps/wcm/connect/51507fdb-dded-47f7862d-ad80c3ee1738/MLG-5.pdf?MOD=AJPERES. /Accessed March 3, 2017/

Verraes C., Van Boxstael S., Van Meervenne E., Van Coillie E., Butaye P., Catry B., Daube G. 2013. Antimicrobial resistance in the food chain: a review. Int. J. Environ. Res. Public Health 10: 2643-2669.

WHO. 2011. E. coli enterohemorrágica (EHEC). World Health Organization. Diciembre de 2011 . Nota descriptiva $\mathrm{N}^{\circ} 125$. http://www.who.int/mediacentre/factsheets/fs125/es/. / Accessed January 20, 2017/

Zamudio M.L., Meza A., Bailón H., Martinez-Urtaza J., Campos J. 2011. Experiences in the epidemiological surveillance of foodborne pathogens by pulsed field gel electrophoresis (PFGE) in Peru. Rev. Peru. Med. Exp. Salud Publica 28: 128135. 